\title{
The Effect of Content Understanding and Pedagogical Experience on Art Teaching
}

\section{Elizabeth Kowalchuk}

\begin{abstract}
Problem Statement
Greg is student teaching this term and shows every indication he will someday become a successful art teacher. His lessons include study of works of art as well as studio activities, and he approaches teaching as a continuing process of learning and reflection. When Greg talks about teaching art to children, he describes his job as one of simplifying art content into bits of information students can understand. Perhaps for this reason, Greg makes little distinction between his own understanding of art and the content he teaches. How does the depth of Greg's art knowledge influence the substance of his teaching? Although his teaching skills will eventually mature, will his knowledge of art and artists deepen with time as well? Will teaching experience lead him to make connections he does not now make between art content areas? Or, will other factors enhance his understanding of art content for teaching? These questions frame the problem I intend to explore in this study.
\end{abstract}

\section{The Relevance of Teacher Understanding}

The issue of teacher understanding is fundamental to problems now facing the general field of education and the specific area of art education. Both A Nation Prepared: Teachers for the 21st Century (Carnegie, 1986) and Tomorrow's Teachers: A Report of the Holmes Group (Holmes Group, 1986) offer recommendations to improve the quality of education that place teachers and teacher education at the core of the solution. In fact, both publications call for restructuring the way teachers are trained, focusing, among other things, on the depth of content knowledge held by teachers and the way they use their subject matter understandings to make connections between teaching and learning.

Toward Civilization: A Report on Arts Education (NEA, 1988) specifically addresses the importance of quality art teaching and art teachers. In this document, the National Endowment for the Arts states that research in arts education should "focus on matters that can actually improve what is done in the classroom" (p. 105) and include studies of learner knowledge and teaching methodology. All of these publications relate the quality of teacher understanding to the depth of student understanding. Without one, the other is unlikely.

Working Papers in Art Education 1991 
The relationship between art teacher understandings and practice can be viewed as a complicated problem of knowledge transfer: teachers organize and translate what they know about art and pedagogy to content relevant for art teaching. Commonly accepted methods of art teacher preparation emphasize both art content knowledge and pedagogical training. Educators expect that art teachers will both understand and make connections between content areas in ways that are pedagogically effective. However, if content or pedagogical understanding is shallow, fragmented, or incomplete, then the degree to which teachers make connections among art history, criticism, aesthetics, and art making will be limited. This perspective is reinforced by research in psychology and education, indicating connections are difficult to achieve in learners unless they are prompted. Even then, transfer often fails.

Current research on teaching and learning provides evidence that deeper understandings and transfer can be fostered in learners by centering curriculum around related higher order concepts and principles (Perkins \& Salomon, 1988; Prawat, 1989). Can the same be true of art teacher understandings? Do art teachers grasp relationships between art content areas more readily when curricular materials are structured and organized around key ideas and conceptually integrated contextual information? How does pedagogical experience interact with content knowledge to influence teaching? These questions frame the problem addressed in this study.

\section{Overview of Research Methods}

To investigate the effect of art content understanding, pedagogical experience, and contextual information on planning and teaching, a three phase study has been developed. The initial phase will focus on lesson plan development in elementary art classes. To infer the effect of contextual information and teaching experience on lesson plan development, 40 undergraduate art education students and experienced elementary art teachers will plan a lesson that focuses on Edouard Manet's painting entitled Bar at the Follies-Bergere and that includes a studio activity. Participants will be oriented to the task in the same way but will receive different contextual information about the artist and his work. Twenty participants will be given fragmented and shallow information, drawn directly from writings aimed at novice art learners. The remaining participants will read contextual information drawn from writings for art experts and focused around a single key concept.

So that the pedagogical choices art teachers make when presenting lessons can be examined, participants from each level of teaching experience and contextual information in the previous phase will teach the lessons they planned to classes of fourth, fifth or sixth grade students. A follow-up interview will be conducted with each teacher to provide opportunities for reflection and lesson assessment. 
The participant's art content knowledge and approach to pedagogical tasks will be explored in Phase Three. Each participant from Phase Two will complete art sorting activities, discuss art content, and elaborate on typical lesson construction in upper elementary classes. Finally, the teachers will explain how they use their art knowledge in planning and teaching.

\section{Data Analysis}

Data analysis strategies generally recommended for analyzing qualitative data (i.e. Lincoln \& Guba, 1985; Merriam, 1988; Siedman, 1991) will be combined with categories derived from previous research in learning, teaching, and understanding art. First, general themes and specific topics will be identified for comparison from notes made during preliminary readings of the data and from a review of research questions examined in this study. Illustrations of general novice-expert characteristics, explanations of novice-expert differences in understanding art, and descriptions of pedagogical content knowledge will provide a framework for data analysis as well (i.e. Glaser \& Chi, 1988; Grossman, Wilson, \& Shulman, 1989; Koroscik, 1990). Differences between levels of teaching experience and contextual information will be examined discretely between phases, and individual teacher profiles will be developed that examine the relationship between art content and pedagogical understanding and teaching practice.

\section{Expected Results}

It is expected that art knowledge, pedagogical experience, and contextual information will significantly influence how individuals plan and teach art lessons. Shallow subject matter understanding will most probably lead to lessons that lack conceptual focus and depth. Teachers with a shallow knowledge of art and teaching will make superficial connections between art content areas. Pedagogical experience should somewhat mitigate the influence of the contextual information on planning and teaching. However, it is predicted that even teaching experience will fail to counteract a lack of content understanding when teachers plan and teach lessons that require the integration of art history with studio activities. If contextual information is organized around key ideas and conceptual principles, then it is anticipated that even teachers with limited subject knowledge and teaching experience will make connections between the study of art and art making in their planning and teaching. Thus, these results will begin to reveal how art knowledge and experience, and contextual information influences art teaching.

\section{Significance}

In a few months, Greg will begin teaching art in a large suburban district. Although many factors influence his students' learning, Greg's teaching will be at the center of variables that effect what his students will ultimately come to know of art (Carnegie, 1986; Holmes Group, 1986; NEA,

Working Papers in Art Education 1991 
1988). If he presents only partial pictures, treats subject matter superficially, or fails to make connections between content areas, it is unlikely that his students will deeply understand the subject they study.

Research in education has recently focused on the nature and organization of the teacher's knowledge base and its influence on teaching practices (Leinhardt, 1986, Shulman, 1986; Wilson, 1988). Current investigations have found that learning, influenced by prior knowledge, is domain specific (Shuell, 1988). Research in both areas indicates that experts are distinguished from novices in ways that relate directly to the depth, nature, and organization of their domain knowledge. These findings call into question the assumptions made by teacher educators regarding the ease with which teachers learn and apply content knowledge in teaching.

In art education, we assume teachers more than adequately understand art and are able to successfully transform these understandings to content for instruction in pedagogically effective ways. The results of research in related fields, however, demand that art educators examine these assumptions carefully. By focusing on the relationship between content understanding and teaching experience and its effect on art teaching, the results of this research will influence how art educators understand and approach the preparation of art teachers. Furthermore, exploring these variables will move the field of art education closer to an understanding of the knowledge base needed for successful art teaching.

\section{References}

Carnegie Task Force on Teaching as a Profession. (1986). A nation prepared: Teachers for the 21 st century. Washington, D. C.: Carnegie forum on Education and the Economy.

Glaser, R. \& Chi, M. T. H. (1988). Overview. In M.T.H. Chi, R. Glaser, \& M. J. Farr (Eds.), The nature of expertise (pp. Xv-xxviii). Hillsdale, $\mathrm{NJ}$ : Lawrence Erlbaum.

Grossman, P. L., Wilson, S. M., \& Shulman, L. S. (1989). Teachers of substance: Subject matter knowledge for teaching. In M. C. Reynolds (Ed.), Knowledge base for the beginning teacher. (pp. 23-46). Oxford: Pergamon.

The Holmes Group. (1986). Tomorrow's teachers: A report of the Holmes Group. East Lansing, Ml: Author.

Koroscik, J. S. (1990). Novice-expert differences in understanding and misunderstanding art and their implications for student assessment in art education. Journal of the Arts and Learning Special Interest Group, American Education Research Association, 8 (1), 6-29.

Working Papers in Art Education 1991 
Leinhardt, G. (1986). Expertise in mathematics teaching. Educational Leadership, 49 (7), 28-33.

Lincoln, Y. S., \& Guba, E. G. (1985). Naturalistic inquiry. Newbury Park, CA: Sage, 1985.

Merriam, S. (1991). Case study research in education: A qualitative approach. San Francisco: Jossey-Bass.

The National Endowment for the Arts. (1988). Toward civilization: A report on arts education. Washington, D.C.: Author.

Perkins, D. N. \& Salomon, G. (1988). Teaching for transfer. Educational Leadership, 46 (1), 22-32.

Prawat, R. S. (1989). Promoting access to knowledge, strategy, and disposition in students: A research synthesis. Review of Educational Research, 59 (1), 1-41.

Shuell, T. J. (1988). The role of the student in learning from instruction. Contemporary Educational Psychology, 13, 276-295.

Shulman, L. S. (1986). Those who understand: Knowledge growth in teaching. Educational Researcher, 15, 4-14.

Seidman, I. E. (1991). Interviewing as qualitative research: A guide for researchers in education and the social sciences. New York: Teachers College Press.

Wilson, S. M. (1988). Understanding historical understanding: Subject matter knowledge and the teaching of U. S. history. Unpublished doctoral dissertation, School of Education, Stanford University, CA. 